\title{
BALSAM FIR ADVANCE GROWTH AFTER CUTTING IN QUEBEC 1
}

\author{
By R. J. HATCHER ${ }^{2}$
}

\begin{abstract}
Two investigations were made in Quebec on the growth of balsam fir advance growth after logging. Younger and smaller seedlings responded faster and better to the release than older and taller seedlings; a direct relationship existed between seedling height growth before release and height growth subsequent to release.
\end{abstract}

\section{RESUME}

Deux enquêtes ont été menées au Québec sur la croissance de semis préexixtants de sapin baumier après des opérations de coupe. Les plants les plus jeunes et les plus petits se sont développés plus rapidement et mieux, après dégagement, que les sujets plus âgés et plus gros; il existait un rapport étroit entre la croissance en hauteur des plants avant dégagement, et leur croissance en hauteur après dégagement.

\section{INTRODUCTION}

In Eastern Canada most balsam fir stands ${ }^{3}$ originate from advance growth present beneath the canopy of the old stand. A knowledge of the factors governing development of this reproduction following logging is basic to the evolution of sound silvicultural practices for the species. Of the many factors involved, the influences of seedling height, age and height growth prior to partial cutting were studied in 1959 at the Lake Edward Experimental Forest north of Grand'Mere, Quebec. The trends evident in this study were confirmed in 1961 by a similar but more limited investigation of smaller-sized advance growth at Epaule River in the Laurentide Park, north of Quebec City.

\section{Materials and Methods}

At Lake Edward, 199 fir seedlings were studied in uneven-aged spruce-firyellow birch stands on the Oxalis-Cornus site type (Heimburger, 1941) that were cut in 1955-1956 under a diameter limit that removed approximately one-half of the growing stock. All fir advance growth (1-12 feet tall) was sampled on systematically spaced circular plots 15 feet in radius. For each seedling, total height and annual height growth for three years before and three years after logging were recorded in the field. Age was determined in the laboratory from discs cut at the root collar.

At Epaule River the analysis comprised 81 seedlings that were between 0.5 and 1.0 foot tall when 50 per cent of the growing stock was selectively cut from a dense 50-year-old fir stand on the Hylocomium-Oxalis site type (Linteau, 1955).

${ }^{1}$ Dept. of Forestry, Canada, Forest Research Contribution No. 542.

${ }^{2}$ Research Officer, District Forest Office, P.O. Box 35, Sillery, P.Q.

${ }^{8}$ Nomenclature as in Native Trees of Canada, Bulletin 61. Canada, Department of Forestry, 6th Ed. 1961. 


\section{RESULTS}

Seedling height at the time of release had a marked effect upon subsequent height growth (Figures 1 and 2). Small seedlings grew faster than large seedlings. This trend became most evident during the second and third growing seasons. During the third growing season, seedlings that were initially in the 1-and 2-foot height classes grew at least twice as fast as those of comparable vigour in the 5-foot class or larger. Vigour was expressed in terms of height growth in the three years prior to release.

The effect of age at the time of release on height growth (Figures 3 and 4) was similar to the effect of initial height. Young seedlings grew more rapidly after release than old seedlings. Notably, the older seedlings at Lake Edward grew as fast as or faster after release than the young seedlings at Epaule River. Probably this is because Oxalis-Cornus sites are of better quality than Hylocomium-Oxalis.

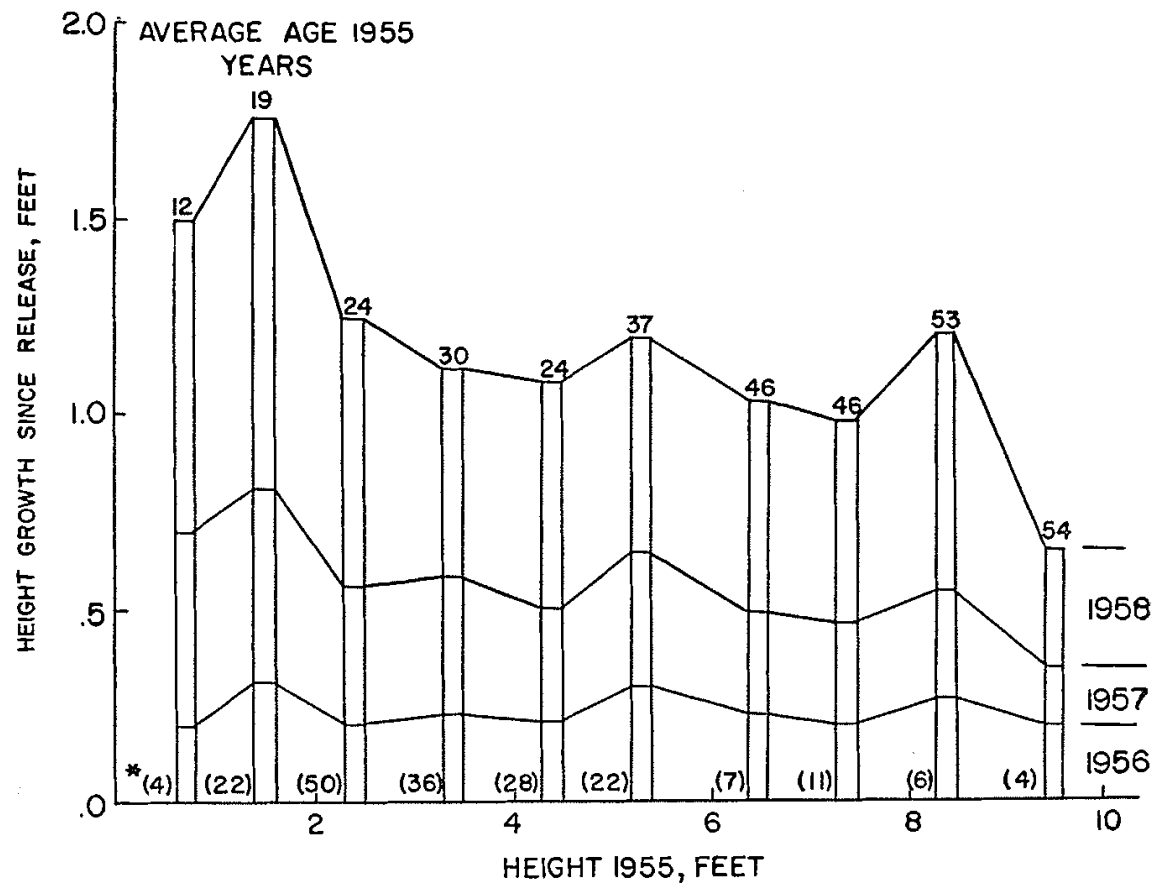

FIGURE I. RELATIONSHIP OF HEIGHT GROWTH AFTER LOGGING TO HEIGHT PRIOR TO LOGGING, LAKE EDWARD.

* number of samples 

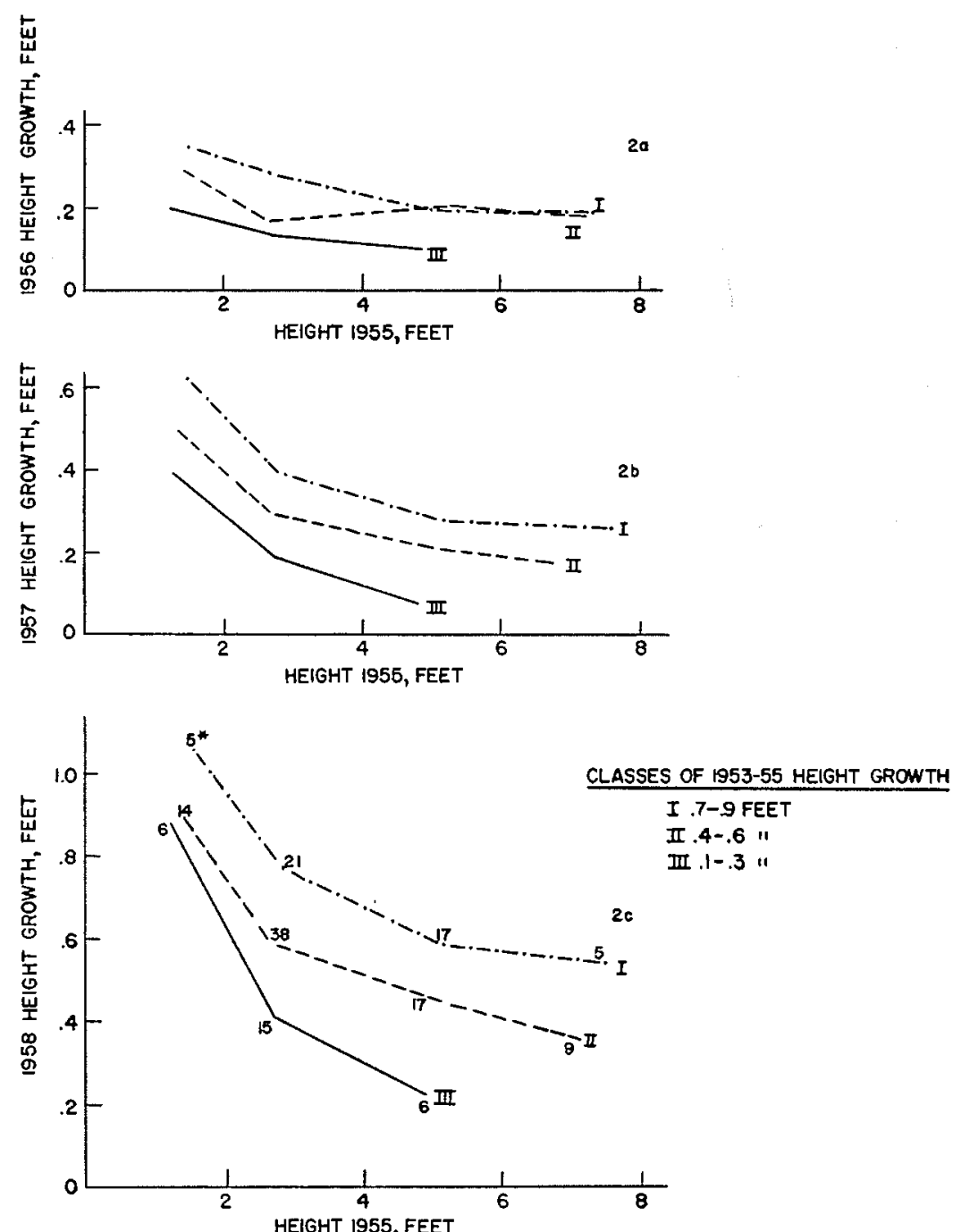

FIGURE 2. RELATIONSHIP OF HEIGHT GROWTH 1956,1957,1958 TO HEIGHT AT TIME OF RELEASE AND HEIGHT GROWTH PREVIOUS TO RELEASE LAKE EDWARD

* number of samples 


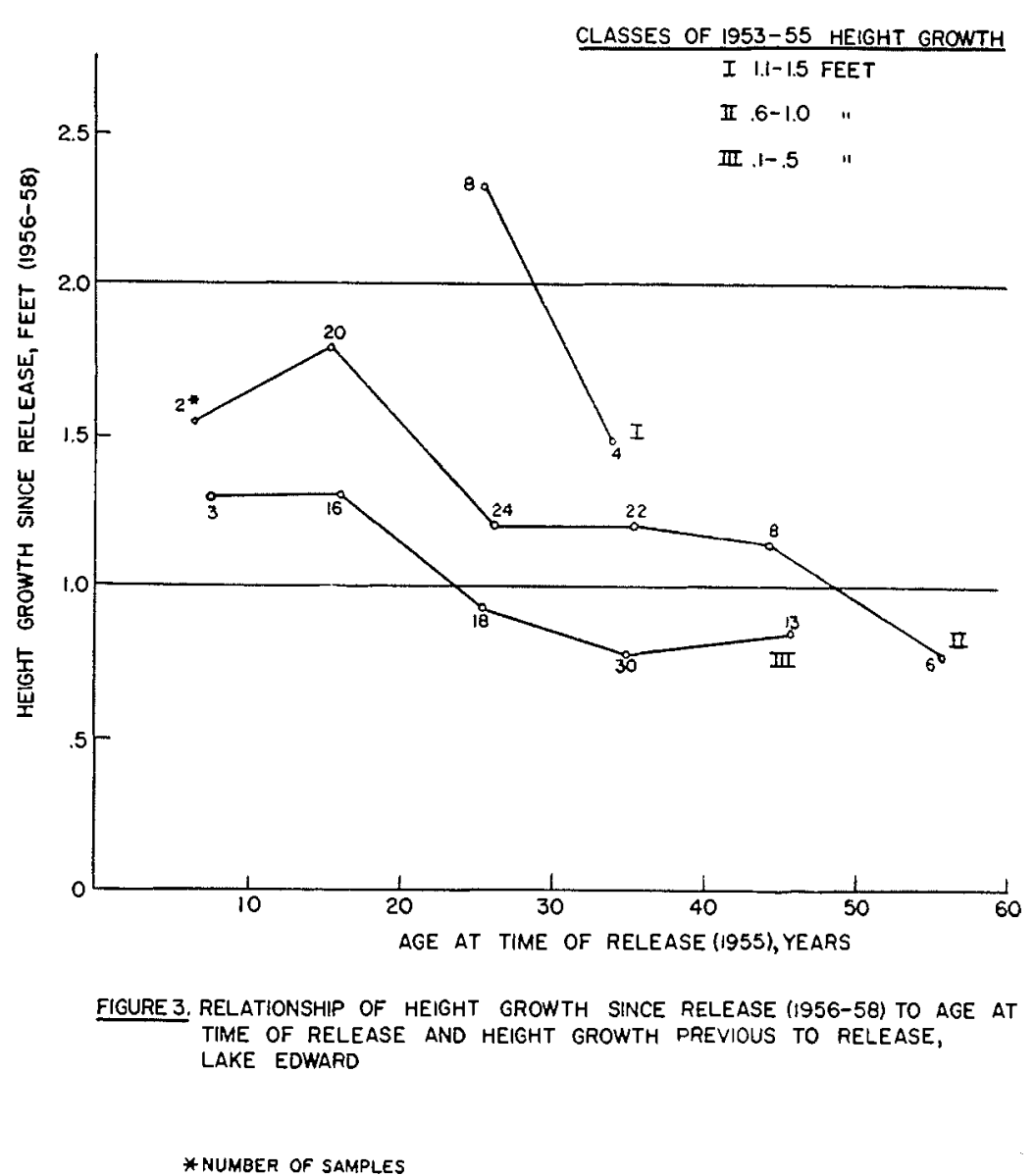

Within a given height or age class, height growth following release was directly related to vigour of the seedling at the time of release. The pattern or trend of height growth (accelerating, decelerating or constant) in the three years preceding release also bears a relationship to subsequent height growth. Trees accelerating in height growth before the logging grew faster after release than did those having a constant or decelerating growth (Figure 5).

Younger seedlings generally responded more promptly to release by logging than the older seedlings (Table 1). For example, in the second year following release, all of the seedlings under 10 years of age showed a definite increase in diameter growth, but in the older age classes, only 36 to 79 per cent of the seedlings had responded. 


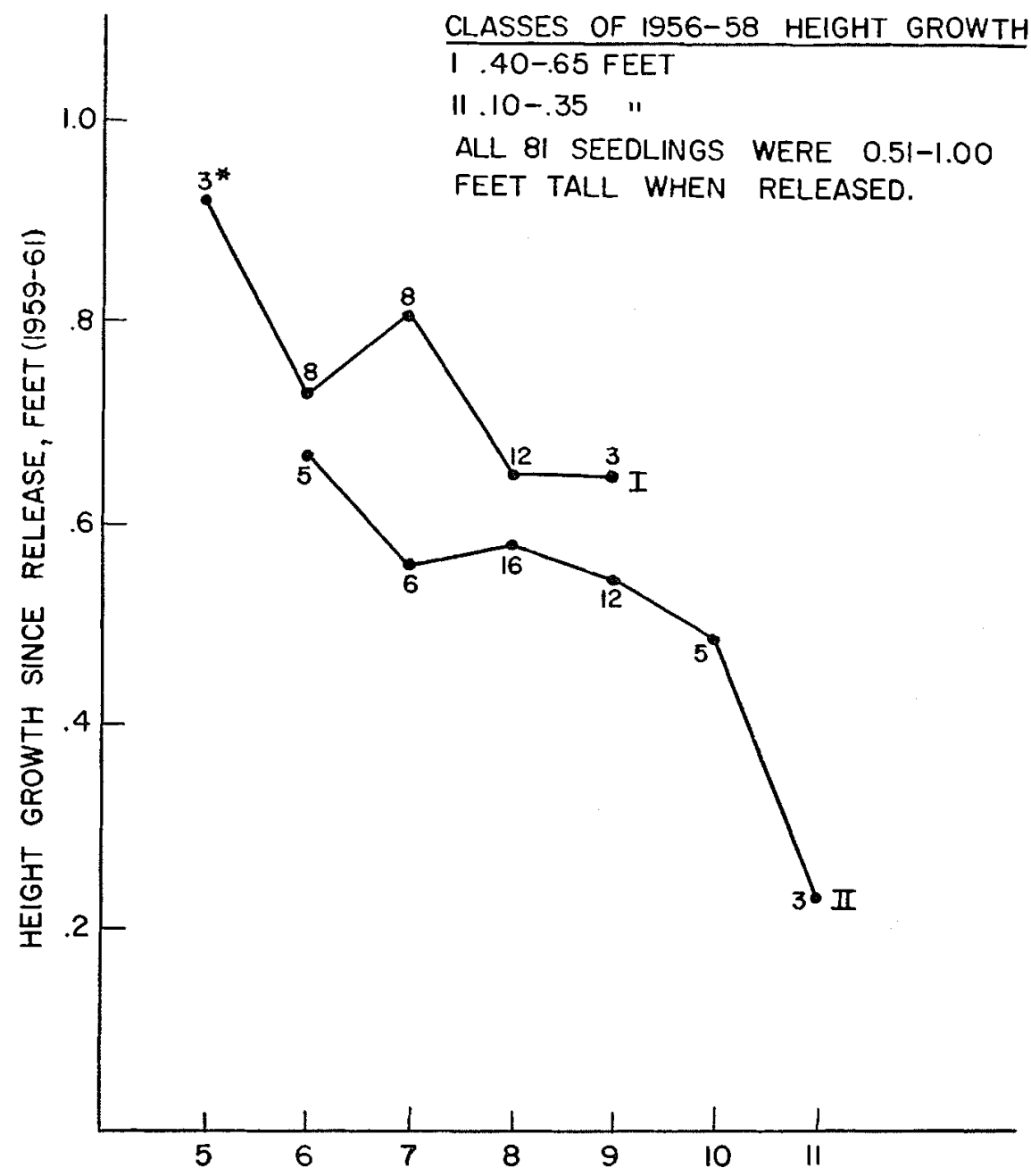

AGE AT TIME OF RELEASE(1955), YEARS

FIGURE 4. RELATIONSHIP OF HEIGHT GROWTH SINCE RELEASE (1959-61) TO AGE AT TIME OF RELEASE AND HEIGHT GROWTH PREVIOUS TO RELEASE, EPAULE RIVER 
TABLE 1

Relationship Between Promptness of Growth InCrease and Seedling Age, Lake Edward

\begin{tabular}{|c|c|c|c|c|c|c|c|c|}
\hline $\begin{array}{c}\text { Age Class } \\
1955 \\
\text { Years }\end{array}$ & $\begin{array}{l}\text { Number } \\
\text { of } \\
\text { Samples }\end{array}$ & \multicolumn{7}{|c|}{$\begin{array}{l}\text { Camulative Frequeney of Seedling Response, Per Cent } \\
\text { Diameter Growth } \\
\text { Yeight Growth } \\
\text { Year of Increased Growth Following Relense }\end{array}$} \\
\hline $1-10$ & 7 & 43 & 100 & 100 & & 43 & 72 & 100 \\
\hline $11-20$ & 38 & 34 & 79 & 97 & & 29 & 82 & 98 \\
\hline $21-30$ & 51 & 25 & 51 & 80 & & 20 & 44 & 76 \\
\hline $31-40$ & 58 & 17 & 39 & 89 & & 9 & 35 & 73 \\
\hline $41-50$ & 25 & 16 & 36 & 84 & & 20 & 32 & 80 \\
\hline $51+$ & 14 & 7 & 50 & 79 & & 0 & 0 & 71 \\
\hline ALL & 193 & 23 & 53 & 88 & & 18 & 44 & 80 \\
\hline
\end{tabular}

Two samples never suppressed, and four samples of doubtful age were omitted.
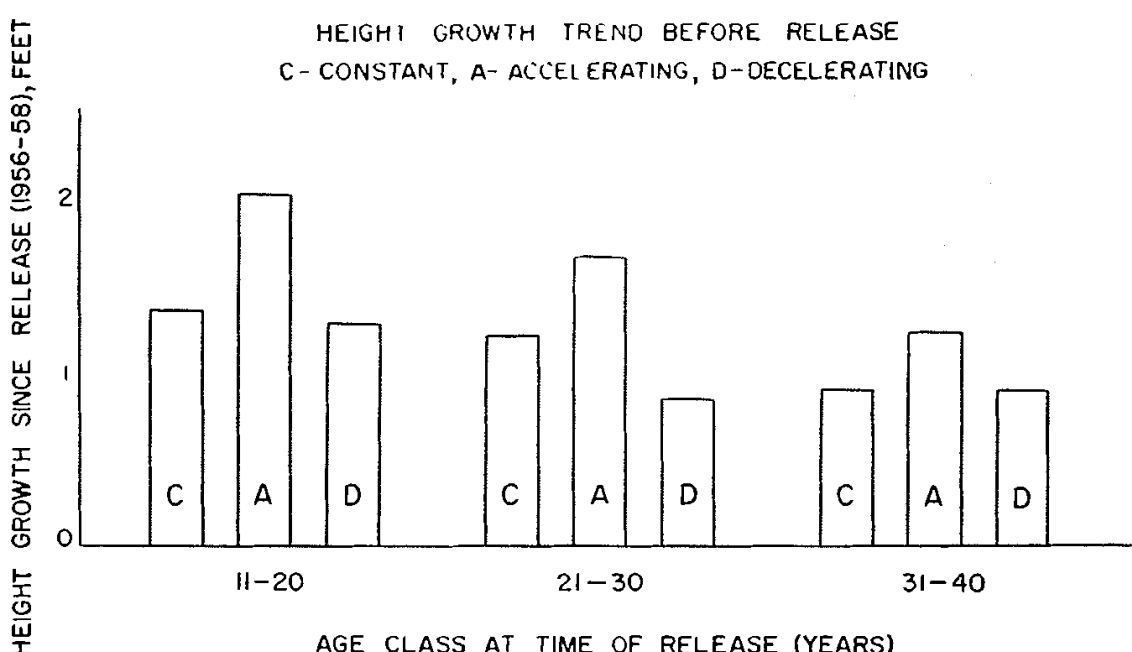

FIGURE 5. RELATIONSHIP OF HEIGHT GROWTH SINCE RELEASE TO PRE-RELEASE GROWTH TREND, BY AGE CLASSES, LAKE EOWARO

\section{Discussion}

The response in growth of fir seedlings to release after logging appears to be related to seedling age, height, and height growth just prior to the release. For seedlings of a given age or height at the time of release, those classed as most vigorous subsequently grew best. For seedlings of equal vigour, the small and young seedlings outgrew the larger and older seedlings in height. Supplementing this superiority is the tendency of young seedlings to respond earlier. 
At Lake Edward, trees in the 1 to 2 foot height class grew the fastest after logging. In Newfoundland, Ellis (1959) reported a most rapid response in fir aged 5-10 years and 4-8 inches tall; in New Brunswick, Baskerville (1961) found the best and most rapid response on stems 4 feet tall at the time of release; and Westveld (1935) reported best response in 2-5 foot stems in northeastern United States. Among the reasons for these somewhat conflicting results are differences in seedling vigour caused by variations in crown canopy, and differences in site quality.

The faster height growth of smaller seedlings following logging may be expected to result in a modest reduction in the original height differences of the reproduction and a tendency towards the development of a uniform sapling storey. Repeated diameter limit logging at Lake Edward conceivably could have the effect of producing a multi-storied stand structure quite unlike the uneven-aged structure of the past.

Seedling response following logging was rapid, with 88 per cent of the stems showing increased diameter growth, and 80 per cent showing increased height growth, within three years. This quick reaction suggests a partial solution to the problem of fir suppression and mortality caused by shrub competition following logging in mixedwood stands (Vincent, 1956). If advance growth could be released prior to logging, possibly by the application of herbicides to unmerchantable species in the stand, its chances to compete successfully with the influx of shrub growth following logging should be improved. Furthermore, there is some evidence (Baskerville 1961, Mulloy 1941 ) that the beneficial effects of release persist for several years.

\section{REFERENCES}

BASKERVILLE, G. L. 1961. Response of young fir and spruce to release from shrub competition. Can. Dept. of Forestry, For. Res. Div., Tech. Note No. 98.

ELLIS, R. C. 1959. Progress Report - An investigation of the length of the regeneration period and of the field potential of pulpwood cut-over in Newfoundland. Can. Dept. of Forestry, Forest Research Branch, Unpublished report.

HEIMBURGER, C. C. 1941. Forest-site classification and soil investigation on Lake Edward forest experimental area. Can. Dept. of Mines and Resources, Dorm. For. Serv., Silv. Res. Note No. 66.

LINTEAU, A. 1955. Forest site classification of the northeastern coniferous section of the boreal forest region, Quebec. Can. Dept. Northern Affairs and National Resources, For. Br., Bull. 118.

MULLOY, G. A. 1941. Cleaning of scattered young balsam fir and spruce in cut-over hardwood stands. Can. Dept. of Mines and Resources, Dom. For. Serv., Silv. Res. Note No. 67.

VINCENT, A. B. 1956. Balsam fir and white spruce reproduction on the Green River watershed. Can. Dept. Northern Affairs and National Resources, Forestry Branch, For. Res. Div., Tech. Note No. 40.

WESTVELD, M. 1935. Weeding as a stand improvement measure on cut-over spruce lands. U.S. Dept. Agric., For. Serv., Ntheast For. Exp. Sta. Occas. Paper No. 5. 